Article

\title{
Impact of Perceived Risk on Consumers Technology Acceptance in Online Grocery Adoption amid COVID-19 Pandemic
}

\author{
Sufyan Habib ${ }^{1}$ and Nawaf N. Hamadneh ${ }^{2, *(D)}$ \\ 1 Department of Business Administration, College of Administration and Finance, Saudi Electronic University, \\ Riyadh 11673, Saudi Arabia; s.habib@seu.edu.sa \\ 2 Department of Basic Sciences, College of Science and Theoretical Studies, Saudi Electronic University, \\ Riyadh 11673, Saudi Arabia \\ * Correspondence: nhamadneh@seu.edu.sa
}

check for

updates

Citation: Habib, S.; Hamadneh, N.N. Impact of Perceived Risk on Consumers Technology Acceptance in Online Grocery Adoption amid COVID-19 Pandemic. Sustainability 2021, 13, 10221. https://doi.org/ $10.3390 /$ su131810221

Academic Editors

Mingaleva Zhanna, Natalia Vukovic and Lazar Stošić

Received: 7 August 2021

Accepted: 7 September 2021

Published: 13 September 2021

Publisher's Note: MDPI stays neutral with regard to jurisdictional claims in published maps and institutional affiliations.

Copyright: (c) 2021 by the authors. Licensee MDPI, Basel, Switzerland. This article is an open access article distributed under the terms and conditions of the Creative Commons Attribution (CC BY) license (https:// creativecommons.org/licenses/by/ $4.0 /)$.

\begin{abstract}
E-commerce industry has witnessed a phenomenal growth globally due to the sudden spread of the COVID-19 pandemic and the advancement of mobile Internet technology, with fast adaption of online shopping technologies by the customers. Previously, online shopping was only available in a few product categories and to a select group of consumers. The COVID-19 guidelines related to safety, physical distancing, closure, lockdown, and other restrictions have insisted that consumers shop online. Because of e-commerce growth, the grocery (FMCG) industry is also equipped with advanced technologies such as the Internet of Things (IoT), cloud computing, and block chain technology. This paper analyzes the UTAUT2 model and its influence on perceived risk and consumer trust in online purchase intention of grocery categories of products among Indian customers. We tried to analyze the growth potential of new technologies in grocery retail and formulated the hypotheses. The results showed that the spread of COVID-19 pandemic had a significant influence on the online shopping behavior of Indian customers. The outcome of the study partly assists businesses in understanding the impact of the factors of consumer adaption of technology, perceived risk associated with online transaction, consumer trust in online technologies and consumer online purchase intention of grocery products. To promote e-commerce in India, the current study suggests that marketers should try to develop consumer trust and lowering the perceived risk associated with online shopping. Some management implications and future area of study based on empirical findings are also highlighted in the present research work.
\end{abstract}

Keywords: consumer adaption of technologies; consumer trust; perceived risk; online shopping; artificial intelligence; statistical analysis

\section{Introduction}

E-commerce industry has witnessed a phenomenal growth due to the rapid advancement of mobile internet technology and technophile customers. Many traditional industries, such as FMCGs, are attempting to capitalize on the market opportunities presented by transformation and up gradation. Previously, online shopping was only available in a few product categories and to a select group of consumers. The volume of global online commerce has increased significantly, owing to the recent COVID-19 crisis [1,2], which has accelerated the growth of e-commerce. Because of e-commerce growth, the grocery (FMCG) industry is also equipped with advanced technologies such as the Internet of Things (IoT), cloud computing, and blockchain technology. The devastating effects of the COVID-19 pandemic on the global economy as a result of lockdown, physical facility closures, perceived risks, and personal safety concerns [3] are some of the influencing factors building consumer intention to purchase even grocery products online. In recent years, a large number of e-commerce firms have entered the FMCG sector in the hope of creating value and sharing market benefits. Online grocery shopping is becoming an increasingly important part of life for customers all over the world, and it has fundamentally altered 
the way people shop for groceries. Because of the omnipresence of technology and the consumer convenience, online shopping has grown significantly in terms of volume as well as use. The COVID-19 pandemic has motivated consumers to accept technologies and purchase grocery products online. Newer technologies and business models, as well as big data/predictive analytics, indicate that the shopping experience is about to take a quantum leap into an unknown shopping realm [4]. Many studies on customer behavior [5,6], new business models $[7,8]$, retailing technologies such as virtual reality $[7,8]$, and changes in retailing reality in certain shops [7] indicate the relevance of new technology in retailing. Changes in the internet's rapid expansion are now influencing the retail-shopping model, with the use of new technology to enhance the whole consumer shopping process, placing pressure on traditional company strategies to adapt. In the grocery industry, there are three sorts of business models. These include "brick and mortar" used in conventional retail chains, "pure-play" used only by online merchants [9], and "bricks and clicks" used by retailer traders online and offline through their offline chain shop (known as multichannel retailing) [10].

The global spread of the COVID-19 epidemic has changed people's shopping habits and perceptions of e-commerce. The country's enforced lockdown regulations, as well as customers' rising reluctance to venture outside and buy for necessities, have pushed it into e-commerce. Consumers have shifted their purchasing habits away from shops, supermarkets, and shopping malls and toward online portals for products ranging from necessities to branded goods. Indeed, the COVID-19 emergency declared in March 2020 gave a strong boost to food hoarding [5,7] and online shopping for food products, with an increase in the number of customers buying foods online to comply with the rules (particularly social distancing) - and simply to ensure they get the food they want instead of facing empty shelves. The COVID-19 pandemic has posed many challenges before business houses and consumers also. Consumer adaption of technology in exploring online shopping of grocery items has motivated them to choose this topic as subject of research. Many studies have shown that, despite technological advancement, its acceptance and influence in building intention to purchase grocery products online is limited. Two important factors that influence low acceptance of online e-commerce platforms are perceived risk and consumer trust in online transactions. As a result, two fundamental questions arise: (a) what factors influence consumer acceptance of technologies for online grocery shopping? and (b) whether consumer trust and perceived risk associated with online platforms mediate the relationship between consumer acceptance of technology for online grocery purchase intention.

\section{Literature Review and Hypotheses Development}

\subsection{Consumer Trust and Online Grocery Purchase Intention}

Accepting online shopping technologies and facilitating any transactions requires trust. Because it is a virtual transaction, trust is more important in E-commerce than in offline transactions. Consumer trust is critical for increasing consumer acceptance of new technology in online shopping and assisting in the process of e-commerce expansion in various retail product categories [11,12]. Trust is positively influenced by technical security features, simplicity of navigation, information display method, and an individual's verification. Trust is a key component in developing buy intentions and establishing longterm consumer connections for repeat purchases and loyalty. Trust is positively influenced by technical security features, simplicity of navigation, information display method, and an individual's verification. Because cognitive and emotional trust influence consumer acceptance of the ideals communicated, trust also has a hierarchical influence on perceived value [13]. E-retailers should consider that they could achieve greater success if they assure customers that their personal information will be safe, and they can increase their trust by providing facilities that provide more secure transactions when they do online purchasing. According to [14], trust is an evaluation of one's relationships with another person who will carry out certain transactions in line with the expectations of people who 
carry out transactions in an unpredictable environment. This trust does not emerge quickly; it must be nurtured and continuously proven. These considerations lead to the following hypothesis:

Hypothesis 1. Consumers acceptance of technology has a positive impact on online grocery purchase intention.

Hypothesis 2. Consumers trust positively influence the online grocery purchase intention.

\subsection{Perceived Risk and Online Grocery Purchase Intention}

According to available research, consumers continue to believe that using the Internet for purchasing is risky $[15,16]$. Furthermore, whether or not a person makes an online purchase, these perceptions can have a significant and inverse relationship with attitudes and intentions $[17,18]$. Consumers' propensity to order groceries online was observed to be very low. The spread of the COVID-19 pandemic, on the other hand, has compelled many customers to shop online. Despite technological advancements and the exponential growth of internet services in business facilitation and retail modeling, organized retailing only accounts for $19 \%$ of the retail market [17-19]. This means that some factors are impeding the growth of online marketing and online transactions in such product categories. One of them is the customer's perception of risk associated with online purchase. Retailers must comprehend the issues associated with perceived risks and devise solutions. The fear of the unknown is the main factor that prevents customers from purchasing via the Internet. Because of a number of problematic causes and concerns, some people have negative impressions about e-commerce purchasing behaviors. The fear of the unknown is the main reason that prevents people from purchasing through the Internet. Some people have bad impressions about e-commerce purchasing activities owing to a variety of problematic causes and worries. While both security and privacy are essential, clients are more concerned about security than privacy. If online clients' actual purchase experiences diverge from their purchasing intentions, they will perceive a higher level of risk [19]. According to Cox and Rich [20], perceived risk is determined by the subjective ambiguity of the consequences. Consumers will have multiple buying goals or expected results of purchasing items or services for each purchase choice. Several forms of perceived risk have been widely employed in past study, and it has been discovered that consumers appear to be cautious while purchasing online [20]. Pentz et al. [21] explored the consumer adaption of digital technologies in online shopping and found significant different in dimension of perceived risk in online shopping among experience and inexperienced online shoppers for different categories of products. Pham and Awan [22] found COVID-19 played a moderating role in consumer utility awareness, which encouraged shoppers to shop online. However, society's affection may be a factor in consumers' reluctance to shop online. Meanwhile, contrary to previous research, awareness of the COVID-19 pandemic and marketing policies have no significant impact on online shopping during the COVID-19 pandemic. According to the previous research findings, perceived risk is an important factor in explaining consumer behavior. As previously stated, consumer purchase intention and purchase behavior can be viewed as an example of risk-taking, based on the fact that any action taken by consumers will have consequences that they cannot predict with any degree of certainty, and at least some of which are likely to be unpleasant If perceived risk is powerful in explaining customer behavior, consumers' reluctance to purchase online could be a direct result of perceived risk, particularly in emerging markets. Based on the preceding discussion, the following hypothesis is proposed:

Hypothesis 3. Consumers perceived risk positively influence the online grocery purchase intention. 


\subsection{Consumer Technology Acceptance, Perceived Risk, Trust and Online Grocery Purchase Intention}

The relationship between consumer trust, perceived risk, consumer acceptance of technology in online purchase of FMCG product has been extensively searched in many studies. A review of the literature on some of the factors of consumer acceptance of online grocery shopping is presented below. It has been demonstrated that social influence has a major impact on human behavior in general and technology adoption (TA) in particular. Several studies have been done to investigate the function of social impact in the adaption of online shopping technologies, and it has been shown that social identity and group norm have substantial effects on consumer involvement. Positive social influence has been found to enhance the link between beliefs and attitudes regarding online buying, as well as the relationship between attitude and shopping intention. In terms of consumer online shopping behavior, authors like Pascual-Miguel et al. [23] and Ingham et al. [24] indicated that social influence may be handled through the impact of individuals like family, friends, and coworkers to whom the customer could seek knowledge or social approbation to utilise online shopping. The previous work related to many online buying research like Zhou, T. [25], Lorenz et al. [26]. Matthew et al. [27] (have confirmed the impact of social influence on consumer intention to use online shopping.

Venkatesh et al. [28] define effort expectancy as the amount of comfort associated with the use of any system. This means that effort expectation relates to the amount of work required utilising the system, regardless of how simple or complex it is. Users may readily embrace and utilise user-friendly technologies. As a result, effort expectation is expected to have a significant influence on buyers' intentions to use online purchasing. Ingham et al. [24] experimentally revealed a strong relationship between perceived ease of use (as a comparable factor to effort expectation) and customer attitudes about online purchasing. Pascual-Miguel et al. [23] recently confirmed that females' desire to use online shopping is significantly predicted by the function of effort expectation, while this link is more likely to disappear for male groups. Mandilas et al. [29] found a substantial direct link between perceived ease of use and customer intent to utilise online purchasing.

The extent/degree to which an individual feels that adopting the system would help him/her achieve increases in work performance is referred to as performance expectation [28,30]. This element, like perceived usefulness from TAM, is acknowledged as a critical component in shaping an individual's attitude toward utilizing any technology [31,32]. According to [33], the degree to which a person believes that using a certain biometric technology will fulfil the organization's security access demands in a specific region is referred to as performance expectation. Indeed, either performance expectation or an equivalent concept captures the cognitive gains expected while utilising a new technology. Importantly, such benefits have been widely seen to have a substantial effect on people's perceptions and desire to embrace various types of apps [34-36]. Customers' intentions to utilize online shopping were also found to be significantly predicted by the function of perceived usefulness, a concept related to performance expectation. Performance expectation has been found to specifically, substantially, and favorably impact one's behavioral intention to adopt and use an IT system [36,37]. Facilitating conditions refer to a person's belief that organizational and technological infrastructure exist to facilitate system utilization [28]. It refers to external elements such as infrastructure and resources that influence the desire to buy food online in the context of this study. Hedonic motivation refers to the effect of a person's pleasure and pain receptors on their desire to go towards a goal or away from a hazard. The capacity of the web and e-commerce platforms to give hedonic, non-functional value to online consuming experiences is widely known, as is the importance that customers place on hedonic benefits. Martnez-López [38] developed a perceptual behavior theory (PBT) and applied the technology acceptance model (TAM) to explore the influence of trust, perceived danger, perceived utility and perceived ease of use on purchase intention. 
The relationship between consumer trust, perceived risk, consumer acceptance of technology in online purchase of FMCG product has been extensively searched in many researchers. Bianchi and Andrews [39] examined the influence of trust and risk on the purchase behavior of Latin American consumers. Perceived risk and trust variables, according to the data, had a favorable effect on the desire to continue shopping online. Consumer attitude influences their propensity to buy online, and perceived danger has an inverse connection with attitude. Juaneda-Ayensa et al. [40] examined the major determinants of technology adoption and use, as well as their influence on buy intent, which underlies multi-channel consumer behavior. Nagy and Noémi [41] investigated how consumers adopt and use Artificial Intelligence (AI)-powered online shopping. The study looks at consumer trust and acceptance of AI in online retail. An online survey was conducted in Hungary to create a database of 439 respondents for this study. Trust was discovered to be one of the most important factors influencing consumer attitudes toward AI. The other key factor in attitudes and behavioral intention was discovered to be perceived usefulness, which was found to be more important than perceived ease of use. According to a similar study by [42], consumers still have the choice whether to use new technology, such as shopping online in an AI web shop, or not. Arguments leads to the following hypothesis (see Figure 1).

Hypothesis 4. Consumer trust mediates the relationship between consumer adaption of technology and online grocery purchase intention.

Hypothesis 5. Consumer perceived risk mediates the relationship between consumer adaption of technology and online grocery purchase intention.

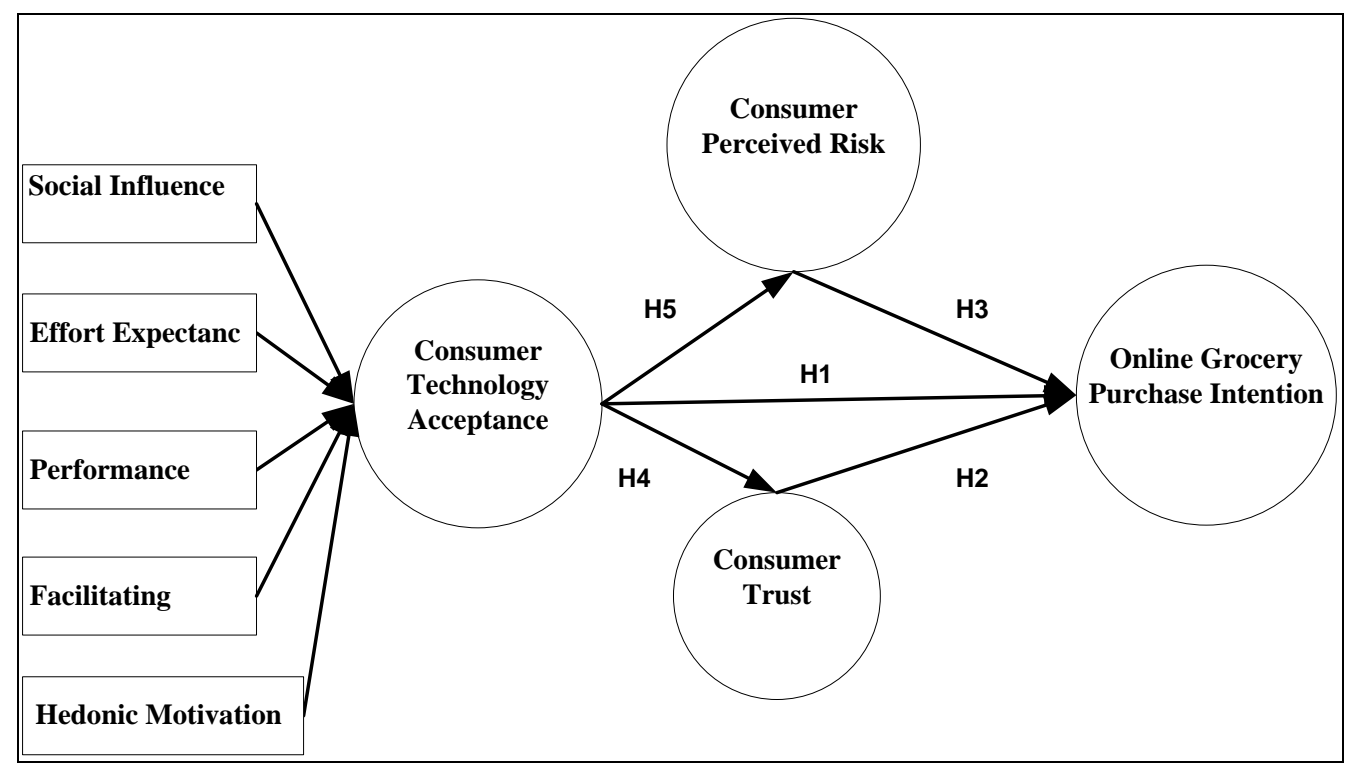

Figure 1. Conceptual Framework.

\subsection{Objectives and Research Methodology of the Study}

The main objective of the study is described as follows:

a. To identify the factors of customers acceptance of technology in adaption of online grocery purchasing during the COVID-19 pandemic.

b. To access the factors of consumer technology acceptance and its influence on online grocery purchasing.

c. To analyze the role of consumer trust and the perceived risk associated with online purchasing of grocery items and the relationship between consumer acceptance of online technology and purchasing intentions for grocery items. 
The present study employed a descriptive research design. Data for the current study were gathered from Indian consumers via an online survey created on Google forms and administered over a two-month period from February-March 2021. Consumers were asked to participate in the study through email and by posting invitations on well-known websites using snowball sampling. Snowball sampling is a technique in which research participants recruit additional participants for a test or study. It is utilized when finding suitable participants is difficult. This sampling approach entails primary data sources recommending additional prospective primary data sources for use in the research. In the current study, a questionnaire was originally distributed to possible respondents, who were requested to complete it and forward it to a known one. There were three sections to the survey questionnaire. The first section included questions about respondents' demographic profiles and motivations for purchasing online grocery items. The second part of the questionnaire contains attributes related to variables influencing consumer adaptation of technology in online grocery shopping based on previous work of $[30,43]$. The third section of the questionnaire focuses on consumers' perceived risk and level of trust in online shopping technologies. Previous work of $[39,44]$ identified measurement variables for measuring consumer trust and perceived risk. Based on the previous work of [45], the fourth part of the questionnaire consists of items related to consumer online grocery purchase intention was developed.

Respondents were asked to express their level of agreement with key traits on a five-point Likert scale (where five designated as strongly agree and one designated as strongly disagree). A panel of three marketing academics reviewed the first questionnaire, assessing its content's validity, the clarity of its item meaning, and the associated linkages of discovered variables with the research objectives. The questionnaire was tested for reliability with 45 respondents, representing $10 \%$ of the overall sample size, who were thought to be typical of the research population. Cronbach's alpha was found to be 0.946 for the full survey, indicating that the questionnaire had an acceptable level of reliability. Researchers received 479 responses, and after editing, 443 were found to be suitable for use in this study, excluding 36 responses that were incomplete or insincerely answered. The collected data was systematically organized, tabulated, and analyzed using SPSS 22.

\section{Results}

The information presented in Table 1 depicts the demographic characteristics of respondents. It is observed that sample is the combination of younger aged respondents as $19 \%$ respondents fall in the age below 20 years. A total of $33.4 \%$ respondents were in the age group of $21-30$ years, $26 \%$ were in the age group of $31-40$ years, $11.3 \%$ were in the age group of $41-50$ years, and the remaining $10.4 \%$ were in the age above 50 years. Males dominate the sample with $70.4 \%$. Regarding education, $25.1 \%$ of respondents were less than graduate, $38.6 \%$ were graduate, and $21 \%$ were postgraduate. Remaining $15.3 \%$ of respondents had professional degrees. Students dominate the sample with $43.6 \%$. Salaried (32.1\%) and business owners (12.9\%) followed it. Homemakers represented by $4.1 \%$ of the sample. $57.1 \%$ of respondents were unmarried while $42.9 \%$ were married. Based on monthly income, 33\% were having monthly income in the range of INR 25,001-50,000. It was followed by INR $50,001-75,000(27.8 \%)$. Only $5.4 \%$ were having monthly income more than INR 100,000. 
Table 1. Demographic Characteristics of Respondents $(N=443)$.

\begin{tabular}{|c|c|c|c|c|c|c|c|}
\hline \multicolumn{2}{|c|}{ Demographic Characteristics } & \multirow{2}{*}{$\begin{array}{c}\mathbf{F} \\
84\end{array}$} & \multirow{2}{*}{$\frac{\%}{19.0}$} & \multicolumn{2}{|c|}{ Demographic Characteristics } & \multirow{2}{*}{\begin{tabular}{|c|}
$\mathbf{F}$ \\
193
\end{tabular}} & \multirow{2}{*}{$\begin{array}{c}\% \\
43.6\end{array}$} \\
\hline \multirow{5}{*}{ Age } & Up to 20 Years & & & \multirow{5}{*}{ Occupation } & Student & & \\
\hline & 21-30 Years & 148 & 33.4 & & Business & 57 & 12.9 \\
\hline & 31-40 Years & 115 & 26.0 & & Salaried & 142 & 32.1 \\
\hline & $41-50$ Years & 50 & 11.3 & & Professionals & 33 & 7.4 \\
\hline & 51 Years \& above & 46 & 10.4 & & Housewives' & 18 & 4.1 \\
\hline \multirow{2}{*}{ Gender } & Male & 312 & 70.4 & \multirow{2}{*}{$\begin{array}{c}\text { Marital } \\
\text { Status }\end{array}$} & Unmarried & 253 & 57.1 \\
\hline & Female & 131 & 29.6 & & Married & 190 & 42.9 \\
\hline \multirow{5}{*}{ Education } & Less than Graduation & 111 & 25.1 & \multirow{5}{*}{$\begin{array}{l}\text { Monthly } \\
\text { Income } \\
\text { (in INR)* }\end{array}$} & Less than 25,000 & 94 & 21.2 \\
\hline & Graduation & 171 & 38.6 & & $25,001-50,000$ & 146 & 33.0 \\
\hline & Post-Graduation & 93 & 21.0 & & $50,001-75,000$ & 123 & 27.8 \\
\hline & Professional & 68 & 15.3 & & $75,001-100,000$ & 56 & 12.6 \\
\hline & & & & & Above 100,000 & 24 & 5.4 \\
\hline
\end{tabular}

* (1 USD = 72.76 INR, as on 26 May 2021).

Information presented in the Table 2 indicates descriptive statistics for various factors related to consumer acceptance of technology for online grocery shopping. Five important constructs were identified based on unified theory of acceptance and use of technology proposed by Vanketesh et al. [30]. Results indicate that factor 'Hedonic Motivation' has the highest mean (3.90). It was followed by 'Facilitating Conditions' (Mean $=3.86$ ) and 'Social Influence' (Mean = 3.84). Factor 'Effort Expectancy' secured the lowest mean value (3.77). Item 'I feel comfortable in using online system for grocery purchase' had the highest mean value (4.01). Item 'It is easy for me to become skillful at online grocery purchase platform' had the lowest mean value (3.65). The reliability of factors was found within the appropriate range (0.679 to 0.765$)$.

Table 2. Consumer acceptance of technology for online grocery purchase $(N=443)$.

\begin{tabular}{|c|c|c|}
\hline Items and Constructs & Mean & SD \\
\hline Consumer Acceptance of Technology & 3.84 & 0.490 \\
\hline Social Influence ( $\alpha=0.765)$ & 3.83 & 0.690 \\
\hline People who are important to me think that I should purchase grocery online. & 3.77 & 0.912 \\
\hline People who influence my behavior think that I should purchase grocery online. & 3.97 & 0.830 \\
\hline People whose opinions that I value prefer that I purchase grocery online. & 3.84 & 0.910 \\
\hline People who influence my behavior think that I should purchase grocery online. & 3.76 & 0.948 \\
\hline Effort Expectancy $(\alpha=0.745)$ & 3.77 & 0.694 \\
\hline My interaction with online grocery platforms is clear and understandable. & 3.70 & 0.916 \\
\hline It is easy for me to become skillful at online grocery purchase platform. & 3.65 & 0.916 \\
\hline I do not need high effort to use online platforms to purchase grocery. & 3.86 & 0.975 \\
\hline $\begin{array}{l}\text { I believe that learning how to use digital technology apps for online shopping grocery items is } \\
\text { easy for me. }\end{array}$ & 3.86 & 0.881 \\
\hline Performance Expectancy $(\alpha=0.736)$ & 3.82 & 0.700 \\
\hline I find online grocery platforms useful. & 3.87 & 0.896 \\
\hline Purchasing grocery online saves my time and enhances my productivity. & 3.88 & 0.994 \\
\hline Online platforms help me in meeting grocery requirements. & 3.71 & 0.960 \\
\hline I believe that online platforms helps me in exploring new grocery options. & 3.82 & 0.898 \\
\hline Facilitating Condition $(\alpha=0.714)$ & 3.86 & 0.628 \\
\hline I have the necessary resources necessary for shopping grocery online. & 3.81 & 0.871 \\
\hline $\begin{array}{c}\text { A required skill and resources is available for assistance while facing difficulties in using online } \\
\text { grocery shopping. }\end{array}$ & 3.82 & 0.948 \\
\hline I believe that I am provided with necessary IT resources needed to purchase grocery online. & 3.74 & 1.024 \\
\hline
\end{tabular}


Table 2. Cont.

\begin{tabular}{rcc}
\hline Items and Constructs & Mean & SD \\
\hline I believe that I have the necessary knowledge to use software. & 3.93 & 0.921 \\
I feel comfortable in using online system for grocery purchase. & 4.01 & 0.820 \\
\hline Hedonic Motivation $(\boldsymbol{\alpha}=\mathbf{0 . 6 7 9 )}$ & $\mathbf{3 . 9 0}$ & $\mathbf{0 . 5 5 3}$ \\
\hline Adapting online shopping of grocery items gives me a pleasing feeling. & 3.92 & 0.764 \\
I feel that online grocery shopping is fun. & 3.86 & 0.818 \\
I feel adapting online grocery shopping is enjoyable. & 3.81 & 0.746 \\
\hline
\end{tabular}

Risk perception and consumer trust in online shopping technology are two important contrasting components affecting consumers' adoption of online grocery shopping. Data presented in Table 3 indicates that consumer perceived risk had mean value of 3.85 and standard deviation of 0.607 . Item 'I feel my disclosed personal information while online grocery purchase are safe' secured the highest mean of 3.92 with standard deviation 0.964 . Consumer trust factor had mean value of 3.62 and standard deviation of 0.638 . Item 'Winning consumer trust in ecommerce is the wisdom of online grocery service providers' had the highest mean (3.71). The reliability of Perceived Risk and Consumer Trust were found 0.824 and 0.867 respectively.

Table 3. Consumers perceived risk and trust in online grocery shopping $(N=443)$.

\begin{tabular}{|c|c|c|}
\hline Item and Construct & Mean & SD \\
\hline Perceived Risk $(\alpha=0.824)$ & 3.85 & 0.607 \\
\hline There is chance of change in the demanded specific products. & 3.83 & 0.844 \\
\hline I feel safe making grocery purchases online. & 3.80 & 0.840 \\
\hline I feel my disclosed personal information while online grocery purchase are safe. & 3.92 & 0.964 \\
\hline Online price offer of grocery products reasonable. & 3.78 & 0.969 \\
\hline Product delivery as promised are done in time. & 3.90 & 0.676 \\
\hline I feel my banking detail given during online transaction are safe. & 3.86 & 0.643 \\
\hline Consumer Trust $(\alpha=0.867)$ & 3.62 & 0.638 \\
\hline I have positive attitude towards internet uses in online shopping. & 3.56 & 0.763 \\
\hline I am familiar and having trust in the vender engaged in online grocery service providers. & 3.58 & 0.790 \\
\hline I trust that vendor engaged in online delivery of grocery will act in a pattern I predict. & 3.61 & 0.858 \\
\hline I trust in the policy for handling of personal information. & 3.58 & 0.801 \\
\hline Winning consumer trust in ecommerce is the wisdom of online grocery service providers. & 3.71 & 0.636 \\
\hline I trust that vendors are having integrity and will not take due advantage of the buyer. & 3.65 & 0.713 \\
\hline
\end{tabular}

Data presented in Table 4 indicates descriptive statistics for various items of consumer intention to purchase grocery online. The reliability and mean of online grocery purchase intention were 0.607 and 4.13 respectively. Item 'I hope that online grocery will a compulsion for every e-commerce platform in future' had the highest mean (4.22).

Table 4. Intention to purchase grocery online $(N=443)$.

\begin{tabular}{ccc}
\hline Item and Construct & Mean & SD \\
\hline Online Grocery Purchase Intention $(\alpha=\mathbf{0 . 6 0 7})$ & $\mathbf{4 . 1 3}$ & $\mathbf{0 . 4 8 5}$ \\
I intend to use the online platform for grocery purchase. & 4.07 & 0.648 \\
I would use online platform for purchasing grocery in the future. & 4.06 & 0.716 \\
I would buy grocery online rather thanany other options available. & 4.19 & 0.826 \\
I hope that online grocery will a compulsion for every e-commerce platform in future. & 4.22 & 0.660 \\
\hline
\end{tabular}




\subsection{Regression Analysis}

In the present research model, the relationship between factors influencing consumer acceptance of technology for online grocery purchase, perceived risk associated with online grocery shopping, consumer trust and intention to purchase grocery online was tested using regression analysis. In examining the concept 'consumer acceptance of technology for online grocery purchase', the combined factor mean (social influence, effort expectancy, performance expectancy, facilitating condition, uses expectancy, and hedonic motivation) was utilized. A similar combined mean of six measurement variables was calculated to examine the constructs of 'customer trust' and 'perceived risk'. Four measurement variables were calculated in relation to consumer online grocery purchase intention. Regression analysis was performed in four steps using SPSS software. In the first step, a regression analysis was performed to determine the direct impact of the consumer acceptance of the technology component of online grocery purchasing. In the next step, the impact of factors of consumer acceptance of technology on consumers' perceived risk and consumer trust was determined. Finally, the impact of consumer perceived risk and consumer trust on consumer online grocery purchase intention was calculated. Results are presented in the Table 5 and Figure 2.

Table 5. Maximum likelihood estimates for model $(N=443)$.

\begin{tabular}{cccccccccc}
\hline Ind. Variable & Dep.Variable & $\boldsymbol{\beta}$ & $\begin{array}{c}\text { Standard } \\
\text { Error }\end{array}$ & $\boldsymbol{t}$-Statistic & $\boldsymbol{R}$ & $\boldsymbol{R}^{\mathbf{2}}$ & $\boldsymbol{F}$-Value & $\boldsymbol{p}$-Value & Results \\
\hline CAT & OPI & 0.766 & 0.030 & 25 & 0.77 & 0.59 & 625.40 & 0.0 & Accepted \\
CAT & CPR & 0.734 & 0.040 & 22.69 & 0.73 & 0.53 & 515.21 & 0.0 & Accepted \\
CAT & CT & 0.723 & 0.043 & 21.98 & 0.72 & 0.52 & 483.37 & 0.0 & Accepted \\
CPR & OPI & 0.655 & 0.029 & 18.19 & 0.66 & 0.43 & 331.09 & 0.0 & Accepted \\
CT & OPI & 0.639 & 0.028 & 17.46 & 0.64 & 0.41 & 305.03 & 0.0 & Accepted \\
\hline
\end{tabular}

$\mathrm{CAT}=$ consumer acceptance of technology for online grocery purchase; OPI = online purchase intention; $\mathrm{CT}=$ consumer trust; $\mathrm{CPR}=$ consumer perceived risk; $\beta=$ standardized estimate.

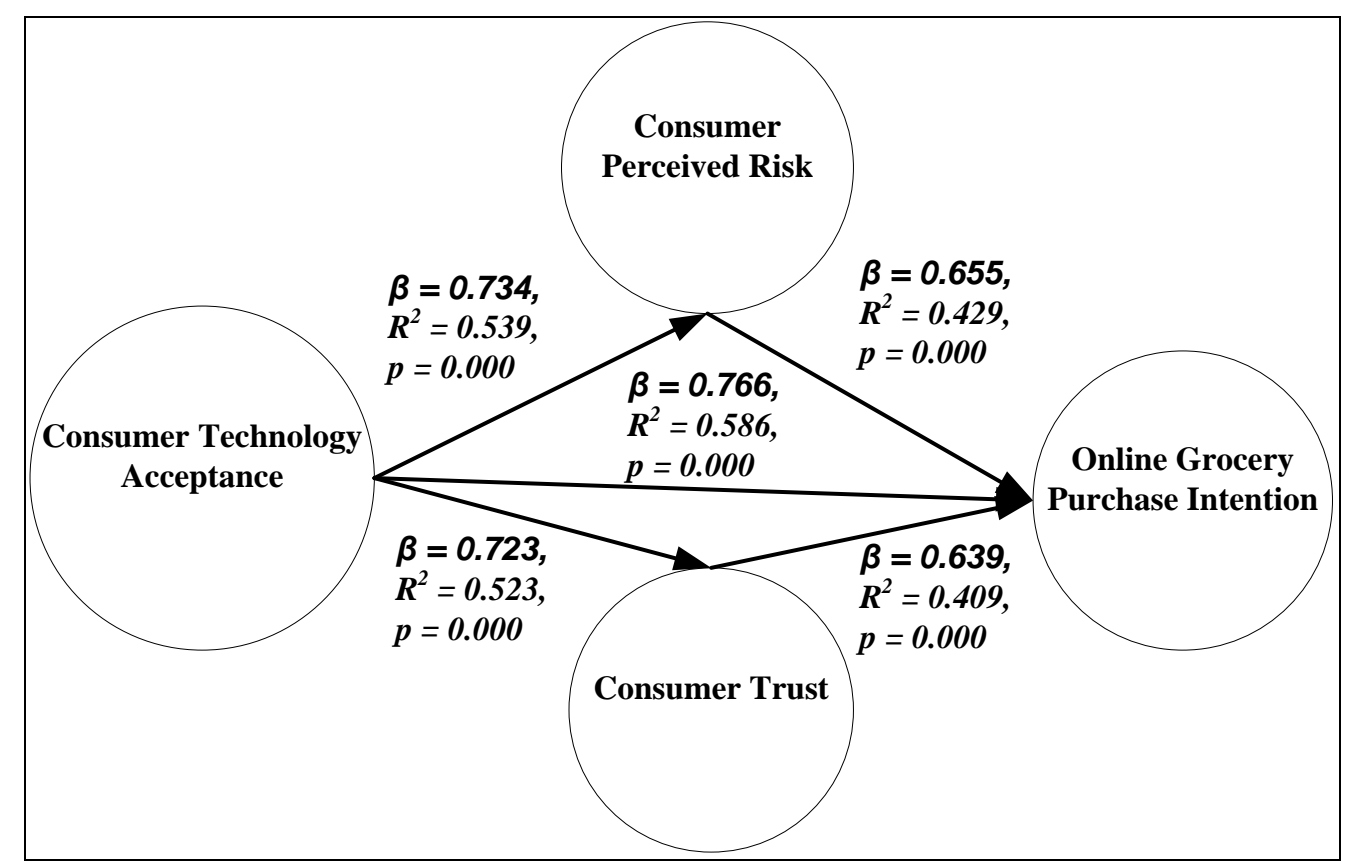

Figure 2. Estimates.

The information presented in the Table 5 and Figure 2 indicates that the direct effect of consumers acceptance of technology on online grocery purchase was found significant $(F=625.401, t=25.008, p=0.000)$ and contributed $58.6 \%\left(R^{2}=0.586\right)$ to online purchase 
intention. It has significant effect on online purchase intention of grocery products. Hence, the research hypothesis is accepted indicating the consumer acceptance of technology has significant effect on consumers' online grocery purchase intention.

Further, the indirect impact of consumer acceptance of technology on online grocery purchase intention via consumer perceived risk and consumer trust was calculated. The results indicated that the impact of consumer acceptance of technology on consumer perceived risk was found as significant $(F=515.215, t=22.696, p=0.000)$ and contributed $53.9 \%\left(R^{2}=0.539\right)$ to online grocery purchase intention. The results revealed that the beta value for factor of consumer acceptance of technology is 0.734 and it has significant effect on consumer perceived risk associated with online shopping. Hence, the research hypothesis is accepted indicating that impact of factors of consumer adaption of technology on consumer perceived risk was fond significant. The impact of factors of consumer acceptance of technology for purchasing grocery online on consumer trust was found significant $(F=483.375, t=21.986, p=0.000)$ and contributed $52.3 \%\left(R^{2}=0.523\right)$ to consumer trust. The results revealed that the beta value for factors of consumer adaption of technology is 0.723 and it has significant effect on consumer trust. Hence, the research hypothesis is accepted indicating the consumer acceptance of technology has significant effect on consumers' trust.

Further the impact of consumer risk perception on online grocery purchase intention was tested and found significant $(F=331.090, t=27.871, p=0.000)$ and contributed $42.9 \%$ $\left(R^{2}=0.429\right)$ to consumer online purchase intention. The results revealed that the beta values consumer trust is 0.655 and it has significant effect on consumer online purchase intention. Hence, the research hypothesis is accepted indicating the consumer perceived risk has significantly influence on consumer online grocery purchase intention. The impact of consumer trust on online grocery purchase intention was found significant $(F=305.030$, $t=17.465, p=0.000)$ and contributed $40.9 \%\left(R^{2}=0.409\right)$ to consumer purchase intention. The results revealed that the beta value of consumer opinion is 0.639 and it has significant effect on consumer grocery online purchase intention. Hence, the research hypothesis is accepted indicating the consumer trust has significant effect on consumers' online grocery purchase intention. Note that, the normal probability test was carried out with the help of SPSS software for assessing whether a data set is approximately normally distributed. SPSS automatically gives a normal probability plot, specifically a P-P plot. Normally a P-P plot is conducted to compare the observed cumulative distribution function (CDF) of the standardized residual to the expected CDF of the normal distribution. An inspection from the regression standardized residual (Figure 3) was also found to be normally distributed whereby the observed and expected values were found along the line, without any significant departures from it.

\subsection{Mediation Analysis}

A mediator variable describes how or why a relationship between an independent variable and its dependent variable is observed. Mediators are variables that increase the intensity of the relationship between a dependent and an independent variable. The relationship between independent and dependent variables is very weak in the absence of a mediating variable. They can be qualitative or quantitative variables that influence the direction and strength of a relationship, resulting in an interaction effect [32]. In general, mediation can occur if the following conditions are met: (1) the independent variable has a significant influence on the mediator; (2) the independent variable has a significant influence on the dependent variable in the absence of the mediator; (3) the mediator has a significant unique effect on the dependent variable; and (4) the independent variable's influence on the dependent variable and dependent variable. Such considerations can be used to determine whether or not mediation is taking place informally. 


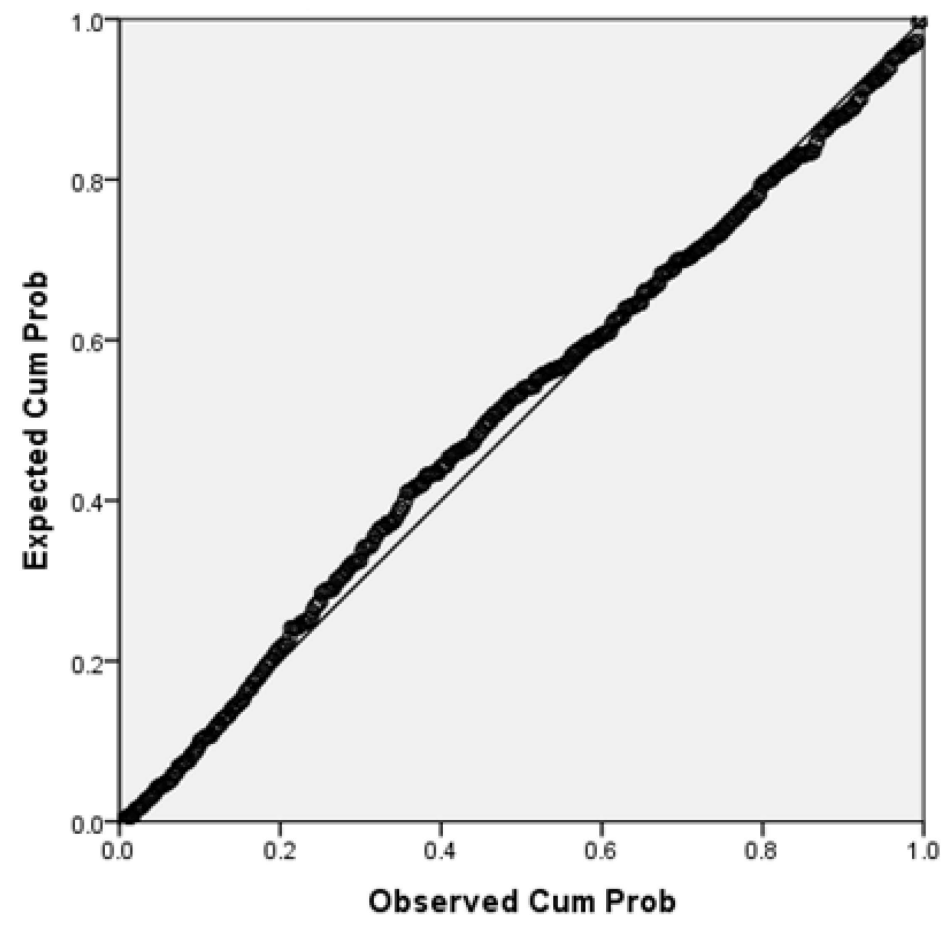

Figure 3. Normal P-P plot of regression standardized residual dependent variable.

\subsection{Consumer Perceived Risk and Consumer Online Grocery Purchase Intention}

Tables 6 and 7 present the findings of the Sobel, Aroian, and Goodman tests, which were used to analyse the effect of a mediating variable (consumer perceive risk) of a given independent variable (consumer acceptance of technology) on a given dependent variable (consumer online purchase intention). The Sobel test revealed that $p$-values are less than 0.05 assuming a two-tailed z-test greater than 1.96, implying that the research hypothesis is accepted and concluded that customer perceived risk mediates the relationship between consumers' acceptance of technology and their intention to purchase groceries online.

Table 6. Influence of Mediating Variable (Consumer perceived Risk) using Sobel Test (A).

\begin{tabular}{cccccc}
\hline & Input & & Test Statistics & Standard Error & $p$-Value \\
\hline $\mathrm{A}$ & 0.710 & Sobel test & 13.32956 & 0.03488 & 0.000 \\
$\mathrm{~B}$ & 0.655 & Aroian test & 13.32105 & 0.03491 & 0.000 \\
$\mathrm{Sa}$ & 0.043 & Goodman test & 13.33808 & 0.03486 & 0.000 \\
$\mathrm{Sb}$ & 0.029 & & & \\
\hline
\end{tabular}

Table 7. Influence of Mediating Variable (Consumer Perceived Risk) using Sobel Test (B).

\begin{tabular}{ccccc}
\hline & Input & & Test Statistics & $p$-Value \\
\hline $\mathrm{t}_{\mathrm{a}}$ & 21.157 & Sobel test & 16.85167 & 0.000 \\
$\mathrm{t}_{\mathrm{b}}$ & 27.871 & Aroian test & 16.84479 & 0.000 \\
& & Goodman test & 16.85855 & 0.000 \\
\hline
\end{tabular}

\subsection{Consumer Trust and Consumer Online Grocery Purchase Intention}

The data in Tables 8 and 9 show the results of the Sobel test, Aroian test, and Goodman test, which were used to assess the effect of a mediating variable (consumer trust in online technologies) of a given independent variable (consumer adoption of technology) on a given dependent variable (online purchase intention). The Sobel test revealed that $p$-values are less than 0.05 assuming a two-tailed z-test greater than 1.96, implying that the research hypothesis is accepted and concluded that customer trust in online technologies mediates 
the relationship between consumer technology adaptation and consumer online purchase intention of grocery products.

Table 8. Influence of Mediating Variable (Consumer Trust).

\begin{tabular}{cccccc}
\hline & Input & & Test Statistics & Standard Error & $p$-Value \\
\hline $\mathrm{A}$ & 0.934 & Sobel test & 27.34689 & 0.03077 & 0.000 \\
$\mathrm{~B}$ & 0.804 & Aroian test & 27.34322 & 0.03077 & 0.000 \\
$\mathrm{Sa}$ & 0.018 & Goodman test & 27.35056 & 0.03076 & 0.000 \\
$\mathrm{Sb}$ & 0.028 & & & & \\
\hline
\end{tabular}

Table 9. Influence of Mediating Variable (Consumer Trust) using Sobel Test (B).

\begin{tabular}{ccccc}
\hline & Input & & Test Statistics & $p$-Value \\
\hline $\mathrm{t}_{\mathrm{a}}$ & 54.761 & Sobel test & 24.97245 & 0.000 \\
$\mathrm{t}_{\mathrm{b}}$ & 28.060 & Aroian test & 24.96915 & 0.000 \\
& & Goodman test & 24.97575 & 0.000 \\
\hline
\end{tabular}

\section{Discussion}

The COVID-19 pandemic has brought phenomenal change in business operation across the world and India cannot be an exception. This study contributes a different perspective, considering how consumer acceptance of technology for online grocery shopping influences consumer trust and reduces the risk of online grocery purchase intention in the Indian context. The findings support that hedonic motivation of consumer and facilitating condition highly influences customers in adapting online shopping technology for purchase of grocery products, and that consumer trust and perceived risk plays as mediating role in the relationship between consumer adaption of technology and online purchase intention of grocery products. The study is in support of previous research that has applied trust as a moderator element to measure its influence on online shopping decisions [46]. Hence, the contribution of this work is the consideration of consumers perceived risk and trust as mediating variable in the relationship between consumer adaption of technology and online grocery purchase intention amid COVID-19 pandemic. The UTAUT model is commonly used to analyze the acceptance of technology. In this research, the UTAUT model is tested on online grocery purchasing.

However, the result showed that hedonic motivation, facilitating conditions and social influence are significant factors in acceptance of online grocery technology. As consumers can see a variety of options, easily compare prices and offers, conveniently add or remove products from a cart and get free home deliveries with discounts, online grocery shopping using smartphone and websites are creating a feeling of excitement and fun. Moreover, modern Indian consumers are well equipped with smartphones, internet connections, which is timely, especially amid COVID-19 lockdown and curfews. These facilitating conditions are also motivating customers to use online grocery platforms for safe and contactless shopping experiences. The role of family members, friends, peers and acquaintances are significant in the acceptance of new technology. These social factors also motivate customers to accept online grocery shopping. Word of mouth communication is commonly used among family, friends and co-workers in the Indian society. Therefore, information on good deals is easily shared. Confidence levels will increase on the application if it is often mentioned in their daily conservation [47].

The impact of perceived risk and customer trust is another significant contribution of the study. Traditionally, consumers feel that shopping groceries online is much tedious if compares to shop ordinary stuff. Besides the low level of awareness, they are skeptical in using the online platforms for grocery purchase. However, amid COVID-19 pandemic, consumers are restricted to shop physically. In addition, consumers are also not interested in going to crowded physical shopping centers. The COVID-19 guidelines related to safety, 
physical distancing, closure, lockdown and other restrictions have influenced consumers to shop online. The findings revealed that the COVID-19 outbreak had a major impact on Indian customers' online shopping behavior. As a result, the research objective of this article has been met, and it helps businesses understand the impact of factors such as consumer technology adaptation, perceived risk associated with online transactions, consumer trust in online technologies, and consumer online purchase intention of grocery products.

\section{Implications and Conclusions}

Based on the findings, the emergence of the pandemic brought changes in consumer perceptions towards contactless shopping. Because of the importance and variety of hedonic motivations in online consumption experiences, company marketing strategists must pay close attention to them when deciding on website design and configuring online media strategies; this is especially important in the current context of social media. Even in online consumption processes that are heavily geared toward achieving instrumental goals. Online grocery marketing firms must continue to promote marketing strategies that stimulate consumer shopping needs by providing more purchasing options, particularly more policies that help customers gain trust in the online system and develop consumer trust in the contactless transaction system. True to reality, hedonic incentive, facilitating conditions, and social influence are all major elements influencing consumer purchasing decisions in India. Before making a purchase, people often seek the advice and opinions of family members or former purchasers. It can be seen that the information India consumers receive from others, whether through any form and means, has a significant influence on the buying decision of them. Perceived risk and customer trust are other important areas for online shopping platforms. The impact of COVID-19 will be apparent for coming months. Online grocery shopping platforms must realize the fact the modern consumers are more concerned about perceived risk and trust associated with technology acceptance. As the number of online frauds and concerns toward privacy and safety have increased, online platforms must explore ways to gain customer confidence and trust. In order to reduce consumer perceived risk and gain their trust, these platforms must focus on their efficient and safe deliveries, clearly demonstrate the values and quality of the product, utilize a user-friendly interface to avoid customer confusion and reduce effort, conduct promotional campaigns to attract potential consumers and provide appropriate information. Referral programs and encouraging satisfied customers to write positive reviews could be the other possible strategies to attract customers and gain their trust. Online grocery shopping platforms need to be more professional, change faster, grasp technology trends to better meet the needs of consumers not only amid pandemic but also in the post pandemic period also as in a long run online shopping trend is expected to grow faster. In particular, the process of return, exchange or refund should also be focused and designed in a simple way to enhance the experience of online shopping for consumers.

\section{Limitations and Future Research}

In the present research, the existence of an issue that has not been fully exploited is inevitable, and this study is no exception. The first is that the study's mediating variable centers only around the looming concern of 2020, which is the COVID-19 pandemic. Second, while age and gender have a big influence on online purchasing decisions, this paper focuses on risk and consumer trust rather than these aspects. Finally, the survey's scope and small sample size limit its applicability in the Indian context.

To avoid this issue in the future, studies should collect data from a variety of sources. The relevance of the finding can be increased by drawing from a bigger group that spans demographics and cultures. The survey in this study is limited to one country, India. This enables follow-up studies to broaden surveys across countries in order to analyze differences in online purchase intentions across economies and cultures.

Author Contributions: Conceptualization, S.H. and N.N.H.; methodology, S.H.; software, N.N.H.; validation, S.H., N.N.H.; formal analysis, N.N.H.; investigation, S.H.; resources, S.H.; writing- 
original draft preparation, S.H. and N.N.H.; writing-review and editing, S.H. and N.N.H.; visualization, S.H. and N.N.H.; supervision, S.H. and N.N.H.; project administration, S.H. and N.N.H. All authors have read and agreed to the published version of the manuscript.

Funding: This research received no external funding.

Institutional Review Board Statement: Not applicable.

Informed Consent Statement: Not applicable.

Data Availability Statement: The data presented in this study are available on request from the first author.

Conflicts of Interest: The authors declare no conflict of interest.

\section{References}

1. Hamadneh, N.N.; Khan, W.A.; Ashraf, W.; Atawneh, S.H.; Khan, I.; Hamadneh, B.N. Artificial neural networks for prediction of covid-19 in Saudi Arabia. Comput. Mater. Contin. 2021, 66, 2787-2796. [CrossRef]

2. Al-Waisy, A.S.; Mohammed, M.A.; Al-Fahdawi, S.; Maashi, M.S.; Garcia-Zapirain, B.; Abdulkareem, K.H.; Mostafa, S.A.; Kumar, N.M.; Le, D.N. Covid-deepnet: Hybrid multimodal deep learning system for improving covid-19 pneumonia detection in chest x-ray images. Comput. Mater. Contin. 2021, 67, 2409-2429. [CrossRef]

3. Kala, D. 'Thank you, God. You saved us'-examining tourists' intention to visit religious destinations in the post COVID. Curr. Issues Tour. 2021, 1-7. [CrossRef]

4. Grewal, D.; Roggeveen, A.L.; Nordfält, J. The future of retailing. J. Retail. 2017, 93, 1-6. [CrossRef]

5. Kim, E.; Libaque-Saenz, C.F.; Park, M.-C. Understanding shopping routes of offline purchasers: Selection of search-channels (online vs. offline) and search-platforms (mobile vs. PC) based on product types. Serv. Bus. 2019, 13, 305-338. [CrossRef]

6. Jocevski, M.; Arvidsson, N.; Miragliotta, G.; Ghezzi, A.; Mangiaracina, R. Transitions towards omni-channel retailing strategies: A business model perspective. Int. J. Retail Distrib. Manag. 2019, 47, 78-93. [CrossRef]

7. Violante, M.G.; Vezzetti, E.; Piazzolla, P. How to design a virtual reality experience that impacts the consumer engagement: The case of the virtual supermarket. Int. J. Interact. Des. Manuf. 2019, 13, 243-262. [CrossRef]

8. Van Esch, P.; Arli, D.; Gheshlaghi, M.H.; Andonopoulos, V.; von der Heidt, T.; Northey, G. Anthropomorphism and augmented reality in the retail environment. J. Retail. Consum. Serv. 2019, 49, 35-42. [CrossRef]

9. Flanc, J.-B. Valuation of Internet Start-Ups: An Applied Research on How Venture Capitalists Value Internet Start-Ups; Anchor Academic Publishing: Hamburg, Germany, 2014.

10. Fleisher, C.S.; Bensoussan, B.E. Business and Competitive Analysis: Effective Application of New and Classic Methods; FT Press: Upper Saddle River, NJ, USA, 2015.

11. Vos, A.; Marinagi, C.; Trivellas, P.; Eberhagen, N.; Skourlas, C.; Giannakopoulos, G. Risk reduction strategies in online shopping: E-trust perspective. Procedia-Soc. Behav. Sci. 2014, 147, 418-423. [CrossRef]

12. Muslikhin, M.; Horng, J.-R.; Yang, S.-Y.; Wang, M.-S.; Awaluddin, B.-A. An Artificial Intelligence of Things-Based Picking Algorithm for Online Shop in the Society 5.0's Context. Sensors 2021, 21, 2813. [CrossRef]

13. Chai, J.C.Y.; Malhotra, N.K.; Alpert, F. A two-dimensional model of trust-value-loyalty in service relationships. J. Retail. Consum. Serv. 2015, 26, 23-31. [CrossRef]

14. Ba, S.; Pavlou, P.A. Evidence of the effect of trust building technology in electronic markets: Price premiums and buyer behavior. MIS Q. 2002, 26, 243-268. [CrossRef]

15. Bourlakis, M.; Papagiannidis, S.; Fox, H. E-consumer behaviour: Past, present and future trajectories of an evolving retail revolution. Int. J. E-Bus. Res. 2008, 4, 64-76. [CrossRef]

16. Drennan, J.; Sullivan, G.; Previte, J. Privacy, risk perception, and expert online behavior: An exploratory study of household end users. J. Organ. End User Comput. 2006, 18, 1-22. [CrossRef]

17. Andrews, L.; Boyle, M.V. Consumers' accounts of perceived risk online and the influence of communication sources. Qual. Mark. Res. Int. J. 2008, 11, 59-75. [CrossRef]

18. Forsythe, S.; Liu, C.; Shannon, D.; Gardner, L.C. Development of a scale to measure the perceived benefits and risks of online shopping. J. Interact. Mark. 2006, 20, 55-75. [CrossRef]

19. Pires, G.; Stanton, J.; Eckford, A. Influences on the perceived risk of purchasing online. J. Consum. Behav. Int. Res. Rev. 2004, 4, 118-131. [CrossRef]

20. Gerber, C.; Ward, S.; Goedhals-Gerber, L. The impact of perceived risk on on-line purchase behaviour. Risk Gov. Control Financ. Mark. Inst. 2014, 4, 99-105. [CrossRef]

21. Pentz, C.D.; du Preez, R.; Swiegers, L. To bu (Y) or not to bu (Y): Perceived risk barriers to online shopping among South African generation Y consumers. Cogent Bus. Manag. 2020, 7, 1827813. [CrossRef]

22. Pham, V.K.; Do Thi, T.H.; Ha Le, T.H. A study on the COVID-19 awareness affecting the consumer perceived benefits of online shopping in Vietnam. Cogent Bus. Manag. 2020, 7, 1846882. [CrossRef] 
23. Pascual-Miguel, F.J.; Agudo-Peregrina, Á.F.; Chaparro-Peláez, J. Influences of gender and product type on online purchasing. J. Bus. Res. 2015, 68, 1550-1556. [CrossRef]

24. Ingham, J.; Cadieux, J.; Berrada, A.M. e-Shopping acceptance: A qualitative and meta-analytic review. Inf. Manag. 2015, 52, 44-60. [CrossRef]

25. Zhou, T. Understanding online community user participation: A social influence perspective. Internet Res. 2011, $21,67-81$. [CrossRef]

26. Graf-Vlachy, L.; Buhtz, K. Social influence in technology adoption research: A literature review and research agenda. In Proceedings of the Twenty-Fifth European Conference on Information Systems (ECIS), Guimarães, Portugal, 5-10 June 2017.

27. Lee, M.K.; Shi, N.; Cheung, C.M.; Lim, K.H.; Sia, C.L. Consumer's decision to shop online: The moderating role of positive informational social influence. Inf. Manag. 2011, 48, 185-191. [CrossRef]

28. Venkatesh, V.; Morris, M.G.; Davis, G.B.; Davis, F.D. User acceptance of information technology: Toward a unified view. MIS Q. 2003, 27, 425-478. [CrossRef]

29. Mandilas, A.; Karasavvoglou, A.; Nikolaidis, M.; Tsourgiannis, L. Predicting consumer's perceptions in on-line shopping. Procedia Technol. 2013, 8, 435-444. [CrossRef]

30. Venkatesh, V.; Thong, J.Y.; Xu, X. Consumer acceptance and use of information technology: Extending the unified theory of acceptance and use of technology. MIS Q. 2012, 36, 157-178. [CrossRef]

31. Durodolu, O.O. Technology acceptance model as a predictor of using information system'to acquire information literacy skills. Libr. Philos. Pract. 2016, 1450.

32. Chau, A.; Stephens, G.; Jamieson, R. Biometrics Acceptance-Perceptions of Use of Biometrics. ACIS 2004 Proceedings. 2004. Available online: https: / / aisel.aisnet.org / cgi/viewcontent.cgi?referer=https: / / www.google.com / \&httpsredir=1\&article=1147 \&context=acis2004 (accessed on 3 September 2021).

33. Ho, G.; Stephens, G.; Jamieson, R. Biometric Authentication Adoption Issues. ACIS 2003 Proceedings. 2003. Available online: https:/ / aisel.aisnet.org/cgi/viewcontent.cgi?article=1319\&context=acis2003 (accessed on 3 September 2021).

34. Alalwan, A.A.; Dwivedi, Y.K.; Williams, M.D. Customers' intention and adoption of telebanking in Jordan. Inf. Syst. Manag. 2016, 33, 154-178. [CrossRef]

35. Rana, N.P.; Dwivedi, Y.K.; Williams, M.D.; Weerakkody, V. Investigating success of an e-government initiative: Validation of an integrated IS success model. Inf. Syst. Front. 2015, 17, 127-142. [CrossRef]

36. Habib, S.; Hamadneh, N.N.; Al wadi, S.; Masadeh, R. Computation analysis of brand experience dimensions: Indian online food delivery platforms. Comput. Mater. Contin. 2021, 67, 445-462. [CrossRef]

37. Habib, S.; Hamadneh, N.N.; Alsubie, A. Modeling Advertising Practices for Product Involvement and Consumer Impulsivity in Branded Apparel: A Case Study of Indian Consumers. Sustainability 2021, 13, 2309. [CrossRef]

38. Martínez-López, F.J.; Pla-García, C.; Gázquez-Abad, J.C.; Rodríguez-Ardura, I. Hedonic motivations in online consumption behaviour. Int. J. Bus. Environ. 2016, 8, 121-151. [CrossRef]

39. Bianchi, C.; Andrews, L. Risk, trust, and consumer online purchasing behaviour: A Chilean perspective. Int. Mark. Rev. 2012, 29, 253-275. [CrossRef]

40. Juaneda-Ayensa, E.; Mosquera, A.; Sierra Murillo, Y. Omnichannel customer behavior: Key drivers of technology acceptance and use and their effects on purchase intention. Front. Psychol. 2016, 7, 1117. [CrossRef] [PubMed]

41. Nagy, S.; Hajdú, N. Consumer Acceptance of the Use of Artificial Intelligence in Online Shopping: Evidence from Hungary. Amfiteatru Econ. 2021, 23, 155-173.

42. Schepman, A.; Rodway, P. Initial validation of the general attitudes towards Artificial Intelligence Scale. Comput. Hum. Behav. Rep. 2020, 1, 100014. [CrossRef] [PubMed]

43. Kim, H.-W.; Chan, H.C.; Gupta, S. Value-based adoption of mobile internet: An empirical investigation. Decis. Support Syst. 2007, 43, 111-126. [CrossRef]

44. Xu, Y.; Chong, T.W.; Krilavičius, T.; Man, K.L. Perceived Benefits, Risks and Trust on Online Shopping Festival; Springer: Berlin/Heidelberg, Germany, 2015; pp. 225-235.

45. Gefen, D.; Karahanna, E.; Straub, D.W. Trust and TAM in online shopping: An integrated model. MIS Q. 2003, 27, 51-90. [CrossRef]

46. Zhang, K.Z.; Cheung, C.M.; Lee, M.K. Examining the moderating effect of inconsistent reviews and its gender differences on consumers' online shopping decision. Int. J. Inf. Manag. 2014, 34, 89-98. [CrossRef]

47. Fang, J.; Wen, C.; George, B.; Prybutok, V.R. Consumer heterogeneity, perceived value, and repurchase decision-making in online shopping: The role of gender, age, and shopping motives. J. Electron. Commer. Res. 2016, 17, 116. 